\title{
Home School Completion
}

National Cancer Institute

\section{Source}

National Cancer Institute. Home School Completion. NCI Thesaurus. Code C70434.

Indicates that a person was instructed in an educational program outside of established schools, especially in the home. 